\title{
Frank(ly), Star(t)ling: A structural protein contributes to changes in left ventricular performance with cardiomyopathies?
}

\author{
Rupak Mukherjee, $\mathrm{PhD}$
}

\author{
From the Division of Cardiothoracic Surgery, Department of Surgery, Medical University of South Carolina, \\ Charleston, SC. \\ Disclosures: Author has nothing to disclose with regard to commercial support. \\ Received for publication Dec 3, 2017; accepted for publication Dec 18, 2017; available ahead of print Jan 26, \\ 2018. \\ Address for reprints: Rupak Mukherjee, PhD, Division of Cardiothoracic Surgery Research, 30 Courtenay Drive, \\ Suite 338, Charleston, SC 29425 (E-mail: mukherr@musc.edu). \\ J Thorac Cardiovasc Surg 2018;156:215-6 \\ $0022-5223 / \$ 36.00$ \\ Copyright (C) 2017 by The American Association for Thoracic Surgery \\ https://doi.org/10.1016/j.jtcvs.2017.12.063
}

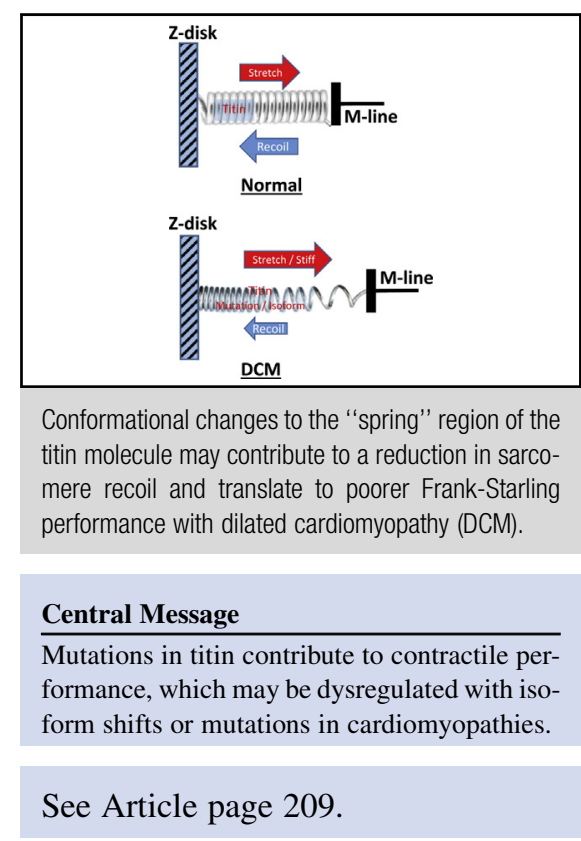

the M-lines of the sarcomeres, and a "spring" region between these anchoring regions. ${ }^{6,8,9}$ Recent work has implicated a functional role for the "spring" region as one of the contributors to the sarcomere length-tension relationship. ${ }^{7,9}$ Specifically, the "folding" of the spring region allows this protein to increase the length under applied force and then to shorten to the original length when the force is removed. ${ }^{7,10}$ This stretchable property of titin contributes to passive stiffness properties before myocyte contraction and restitution of myocyte length at the end of contraction. ${ }^{10}$ Importantly, the presence of different titin isoforms during development or differential expression of splice variants of titin with cardiomyopathies, in particular within the "spring" region, are thought to be one of the prime determinants of changes in myocardial stiffness in these states. ${ }^{11-13}$

In this context, in this issue of the Journal, Stöhr and colleagues ${ }^{14}$ present a brief review of titin, focusing on the physiological role of titin in the generation of the Frank-Starling relationship and discuss some recent findings on the role of titin isoforms and/or posttranslational modifications (oxidation, phosphorylation, glutathionation) with respect to myocardial stiffness. ${ }^{14,15}$ In addition, the authors make the case for genetic variations of titin contributing to the development of hereditary 
cardiomyopathies. ${ }^{16,17}$ Although this review touches on the aforementioned points, the authors do not delve into very many details regarding the functional changes due to the posttranslational modifications of titin, nor do they go very deep into describing the findings from studies that originally described the specific variants of titin with respect to the etiology of cardiac disease. In this respect, the authors refer readers to other, more detailed reviews on this topic. These limitations notwithstanding, a concise review of titin is timely in that it informs readers on how some of the more recent advances in the basic sciences that impinge on better understanding of cardiac physiology as well as changes in left ventricular function with cardiomyopathies.

As a final point, in this review, the authors discuss the potential clinical implications of the basic findings as they may apply to cardiac surgery and to surgical treatment for cardiac pathology. As it stands presently, it seems difficult to envision how the determination of the presence of a particular isoform of titin would dictate clinical judgment on how to direct clinical therapy. An area of intense interest in the recent past has been the implantation of biomatrices within the myocardium as a means to alter the mechanical properties as well as the cellular composition of a region of a myocardial infarction. ${ }^{18-20}$ In that regard, the potential remains that biomatrices may be engineered with titin such that the material characteristics may match the portion of the myocardium in which a particular biomatrix is implanted. For that to happen, however, it remains to be determined what particular conformation of titin would be best suited for this use and the manner in which changes in ventricular geometry and function alter the expression and/or abundance of particular titin isoforms. To realize tangible clinical applications for titin, a better and more thorough understanding of the role of this "titan" protein in physiology and pathophysiology is needed.

\section{References}

1. Frank-Starling law. Available at: https://en.wikipedia.org/wiki/Frank $\%$ E2\% 80\%93Starling_law. Accessed December 3, 2017.

2. Allen DG, Kentish JC. The cellular basis of the length-tension relation in cardiac muscle. J Mol Cell Cardiol. 1985;17:821-40.
3. Moss RL, Razumova M, Fitzsimons DP. Myosin crossbridge activation of cardiac thin filaments: implications for myocardial function in health and disease. Circ Res. 2004;94:1290-300.

4. Takeuchi M, Takaoka H, Odake M, Hayashi Y, Hata K, Yokoyama M. Assessment of left ventricular function using a conductance catheter in the human heart. Jpn Circ J. 1992;56:730-4

5. Glower DD, Spratt JA, Snow ND, Kabas JS, Davis JW, Olsen CO, et al. Linearity of the Frank-Starling relationship in the intact heart: the concept of preload recruitable stroke work. Circulation. 1985;71:994-1009.

6. Buck D, Smith JE III, Chung CS, Ono Y, Sorimachi H, Labeit S, et al. Removal of immunoglobulin-like domains from titin's spring segment alters titin splicing in mouse skeletal muscle and causes myopathy. J Gen Physiol. 2014;143:215-30.

7. Gigli M, Begay RL, Morea G, Graw SL, Sinagra G, Taylor MR, et al. A review of the giant protein titin in clinical molecular diagnostics of cardiomyopathies. Front Cardiovasc Med. 2016;3:21

8. Granzier HL, Radke MH, Peng J, Westermann D, Nelson OL, Rost K, et al. Truncation of titin's elastic pevk region leads to cardiomyopathy with diastolic dysfunction. Circ Res. 2009;105:557-64.

9. Granzier HL, Labeit S. The giant muscle protein titin is an adjustable molecular spring. Exerc Sport Sci Rev. 2006;34:50-3.

10. LeWinter MM, Wu Y, Labeit S, Granzier H. Cardiac titin: structure, functions and role in disease. Clin Chim Acta. 2007;375:1-9.

11. Nagueh SF, Shah G, Wu Y, Torre-Amione G, King NM, Lahmers S, et al. Altered titin expression, myocardial stiffness, and left ventricular function in patients with dilated cardiomyopathy. Circulation. 2004;110:155-62.

12. Granzier HL, Wu Y, Trombitas K, Witt C, Labeit S, Bell S, et al. Variable titinbased stiffness adjustment in heart disease. Circulation. 2003;108:e23.

13. Granzier H, Helmes M, Cazorla O, McNabb M, Labeit D, Wu Y, et al. Mechanical properties of titin isoforms. Adv Exp Med Biol. 2000;481:283-300; discussion 300-4.

14. Stöhr EJ, Takayama H, Ferrari G. Stretch your heart—but not too far: the role of titin mutations in dilated cardiomyopathy. J Thorac Cardiovasc Surg. 2018;156: 209-14.

15. Zile MR, Baicu CF, Ikonomidis JS, Stroud RE, Nietert PJ, Bradshaw AD, et al. Myocardial stiffness in patients with heart failure and a preserved ejection fraction: contributions of collagen and titin. Circulation. 2015;131:1247-59.

16. Gerull B, Gramlich M, Atherton J, McNabb M, Trombitas K, Sasse-Klaassen S, et al. Mutations of TTN, encoding the giant muscle filament titin, cause familial dilated cardiomyopathy. Nat Genet. 2002;30:201-4.

17. Gramlich M, Pane LS, Zhou Q, Chen Z, Murgia M, Schotterl S, et al. Antisensemediated exon skipping: a therapeutic strategy for titin-based dilated cardiomyopathy. EMBO Mol Med. 2015;7:562-76.

18. Mukherjee R, Zavadzkas JA, Saunders SM, McLean JE, Jeffords LB, Beck C, et al. Targeted myocardial microinjections of a biocomposite material reduces infarct expansion in pigs. Ann Thorac Surg. 2008;86:1268-76.

19. Frey N, Linke A, Suselbeck T, Muller-Ehmsen J, Vermeersch P, Schoors D, et al. Intracoronary delivery of injectable bioabsorbable scaffold (IK-5001) to treat left ventricular remodeling after ST-elevation myocardial infarction: a first-in-man study. Circ Cardiovasc Interv. 2014;7:806-12.

20. Sabbah HN, Wang M, Gupta RC, Rastogi S, Ilsar I, Sabbah MS, et al. Augmentation of left ventricular wall thickness with alginate hydrogel implants improves left ventricular function and prevents progressive remodeling in dogs with chronic heart failure. JACC Heart Fail. 2013;1:252-8. 